\title{
PPP3CC Gene
}

National Cancer Institute

\section{Source}

National Cancer Institute. PPP3CC Gene. NCI Thesaurus. Code C38526.

This gene is involved in the regulation of signal transduction. 